\title{
EFEKTIVITAS PELAKSANAAN LAYANAN BIMBINGAN KELOMPOK DENGAN MENGGUNAKAN MEDIA AUDIO VISUAL UNTUK MENINGKATKAN KONSEP DIRI SISWA
}

Siti Muyana ${ }^{1}$, Firman $^{2}$, Syahniar ${ }^{3}$

Email : firman@konselor.org

\begin{abstract}
This research was conducted based on the phenomena indicating that the students seemed to have low self-concept and attitude which was not appropriate to the norms. The aims of this research were to reveal: (1) the students' self-concept in the experimental group before and after the treatment of group guidance service by using audio visual media was applied, (2) the students' self-concept in the control group before and after the treatment of group guidance service without using audio visual media was applied, and (3) the students' self-concept in the experimental group and in the control group in posttest. This research was categorized as a quasi experimental research which applied the non equivalent control group design. The population of the research was the students in class $X$ of SMK Negeri 9 Padang. By using purposive sampling technique, 9 students in class $X J B 7$ were chosen as the experimental group, and 9 students in class X PH 5 were taken as the control group. The instrument used to collect the data was the scale Likert model. The data obtained were analyzed by using Wilcoxon Signed Rank and Kolmogorov Smirnov 2 Independent Samples. The result of the research indicated that: (1) there was a different between self concept of the students in the experimental class in pretest and in posttest, (2) there was no significant different between self-concept of the students in the control group in pretest and in posttest, and (3) there was a significant different between the self concept of the students in the experimental group and in the control group in posttest. Based on the result of the research, it was concluded that group guidance service by using audio visual media was effective to improve the students' self-concept. It was suggested to the upcoming researcher to use the research findings as basis for conducting researches related to the use of audio visual media in group guidance service to improve the students' self concept.
\end{abstract}

\section{Key Terms: Group Guidance Service, Audio Visual Media, Self-Concept}

\section{PENDAHULUAN}

Pendidikan merupakan salah satu upaya untuk memuliakan kemuliaan manusia dengan mengembangkan berbagai kekuatan dan potensi yang dimiliki siswa untuk dapat berguna bagi diri sendiri dan lingkungan.Tujuan pendidikan untuk menjadikan peserta didik, memiliki kekuatan spiritual keagamaan, pengendalian diri, kepribadian, kecerdasan, akhlak mulia dan keterampilan. Berdasarkan tujuan pendidikan tersebut, hendaknya Guru BK atau Konselor sebagai pendidik berupaya untuk membantu siswa agar dapat mengembangkan potensi yang dimiliki siswa dan usaha itu dimulai dengan membantu pemahaman diri siswa dalam mengenali diri pribadi. Erikson (dalam Hurlock, 1980:174) mengemukakan identitas diri pada remaja dalam hal ini adalah siswa merupakan "Kekhususan diri individu yang tergabung dalam kelompok dan memiliki ciri-ciri yang berbeda dengan kelompok tersebut". Siswa cenderung mencari identitas diri dengan mengikuti pola yang berlaku dalam kelompok dan berusaha mengikuti ketentuan yang berlaku dalam kelompok tersebut. Konsep diri dapat terganggu apabila siswa tidak mampu menyesuaikan diri dan mengikuti pola yang sama dengan anggota kelompok. Hurlock (1980:176) mengemukakan seseorang yang memiliki konsep diri ideal biasanya merasa tidak puas pada diri sendiri dan tidak puas pada perlakuan orang lain. Konsep diri yang ada dalam diri siswa tidak terbentuk begitu saja, melainkan melewati masa yang panjang dan terus berkembang dalam kehidupan. Konsep diri terbentuk karena berbagai faktor, antara lain interaksi dengan lingkungan, interpretasi dari lingkungan, pengalaman, atribut dalam diri, dan lain sebagainya. Feldman (2008:380) mengemukakan bahwa konsep diri seseorang menjadi lebih jelas dan lengkap ketika seseorang menambah kemampuan-kemampuan kognitifnya dan berhadapan dengan tugas-tugas perkembangan kanak-kanak, remaja, dan dewasa.

Berikut ini data yang diperoleh dari hasil wawancara dengan Guru BK di SMK Negeri 9 Padang bahwa: (1) layanan bimbingan 
kelompok belum dapat terealisasi karena waktu yang dimiliki siswa sangat terbatas, (2) siswa SMK difokuskan pada praktik atau keterampilan sesuai dengan jurusan masing-masing, (3) penggunaan media audio visual belum dapat terealisasikan karena fasilitas yang dimiliki belum cukup memadai, dan (4) rata-rata siswa mempunyai konsep diri negatif, gejala ini terlihat pada penampilan secara fisik, perilaku membolos, menyontek, datang terlambat, berkelahi, melanggar tata tertib, perasaan rendah diri, dan merasa tidak mampu dalam menyelesaikan tugas. Gejala-gejala tersebut mengindikasikan konsep diri yang dimiliki oleh siswa adalah konsep diri negatif. Sebaliknya, Lecky (dalam Prayitno, 2006:128) mengemukakan bahwa, siswa yang memiliki konsep diri positif menampilkan prestasi baik di sekolah atau siswa yang berprestasi tinggi di sekolah memiliki penilaian diri yang tinggi dan menunjukkan hubungan antar pribadi (baik dengan guru maupun teman sebaya) yang positif. Hurlock (1980:173) mengemukakan konsep diri dipengaruhi oleh faktor-faktor seperti: kondisi fisik, status sosial ekonomi, lingkungan, kemampuan dalam menyelesaikan tugas, intelegensi, dan peran laki-laki dan perempuan.

Berbagai fenomena masalah konsep diri yang terlihat dari berbagai gejala yang tampak pada perilaku yang ditampilkan siswa tersebut sudah seharusnya mendapat perhatian khusus yang menjadi tanggung jawab semua personil sekolah, baik kepala sekolah, guru, karyawan, dan juga dari diri siswa yang bersangkutan. Jika kondisi ini dibiarkan maka dapat berdampak pada perkembangan konsep diri siswa yang cenderung negatif sehingga menimbulkan perilaku yang tidak sesuai dengan norma dan peraturan yang berlaku dalam lingkungannya. Lingkungan kehidupan siswa cenderung tergabung dalam kelompok dan siswa harus mampu mengikuti pola dalam kelompok tersebut. Koughchnet (dalam Prayitno, 2006:129) mengemukakan para siswa cenderung memiliki konsep diri yang lebih tinggi jika dapat belajar berkelompok dan melakukan kegiatan di luar jam pelajaran. Berdasarkan hal tersebut disinilah pentingnya peran Guru BK atau Konselor, yaitu melalui pemberian layanan bimbingan kelompok. Hal ini karena layanan bimbingan kelompok menurut Prayitno (2012:184) mempunyai fungsi pemahaman, fungsi pencegahan, fungsi pengentasan, fungsi pemeliharaan, dan fungsi pengembangan. Berdasarkan fungsi tersebut, diharapkan melalui layanan bimbingan kelompok siswa dapat memiliki pemahaman yang lebih terhadap berbagai hal tentang kehidupan, sehingga dirinya dapat terhindar dari konsep diri negatif yang juga dapat menimbulkan perilaku negatif, dan mampu mengembangkan konsep diri positif yang sudah dimiliki.

Penelitian ini secara umum bertujuan untuk mengetahui efektivitas layanan bimbingan kelompok dengan menggunakan media audio visual untuk meningkatkan konsep diri siswa. Secara khusus tujuan yang ingin dicapai sebagai berikut: (1) perbedaan konsep diri siswa kelompok eksperimen sebelum dan sesudah diberikan perlakuan bimbingan kelompok dengan menggunakan media audio visual, (2) perbedaan konsep diri siswa kelompok kontrol sebelum dan sesudah diberikan perlakuan bimbingan kelompok tanpa menggunakan media audio visual, (3) perbedaan konsep diri siswa kelompok eksperimen yang diberikan perlakuan layanan bimbingan kelompok dengan menggunakan media audio visual, dengan siswa kelompok kontrol yang diberikan perlakuan layanan bimbingan kelompok tanpa menggunakan media audio visual.

\section{METODOLOGI PENELITIAN}

Metode yang digunakan dalam penelitian ini adalah penelitian quasi eksperiment desain the non equivalent control group. Pemilihan subjek penelitian menggunakan purposive sampling dan dipilih dari kelas X SMK Negeri 9 Padang. Sebanyak 9 orang siswa kelas X JB 7 untuk kelompok eksperimen dan 9 orang kelas X PH 5 untuk kelompok kontrol. Uji validitas instrumen penelitian menggunakan Spearman Correlation dengan taraf signifikansi 0,05 dan uji reliabilitas menggunakan rumus Alpha Cronbach. Tingkat reliabilitas instrumen penelitian 0,891 .

Instrumen yang digunakan pada penelitian ini berupa model skala Likert. Data yang telah terkumpul akan dianalisis dengan cara menghitung skor rata-rata konsep diri siswa, Kemudian deskripsi data konsep diri siswa dengan kriteria pencapaian berikut ini.

Tabel 1. Tingkat Pencapaian Konsep Diri Siswa
\begin{tabular}{|l|l|}
\hline \multicolumn{1}{|c|}{ Interval } & \multicolumn{1}{c|}{ Keterangan } \\
\hline $168-200$ & Sangat Baik \\
\hline $135-167$ & Baik \\
\hline $102-134$ & Cukup Baik \\
\hline $69-101$ & Kurang Baik \\
\hline $40-68$ & Tidak Baik \\
\hline
\end{tabular}

Berdasarkan Tabel 1 tersebut dapat dimaknai bahwa semakin tinggi skor konsep diri 
yang diperoleh siswa maka semakin baik tingkat konsep diri siswa, sebaliknya semakin rendah skor konsep diri yang diperoleh siswa, menggambarkan semakin tidak baik tingkat konsep diri siswa. Selanjutnya data yang diperoleh dianalisis dengan menggunakan uji Wilcoxon Signed Ranks Test dan KolmogorovSmirnov 2 Independent Samples.

\section{HASIL DAN PEMBAHASAN}

A. Hasil

\section{Konsep Diri Siswa Kelompok Eksperimen}

Kondisi konsep diri siswa pada kelompok eksperimen sebelum dan sesudah diberikan perlakuan layanan bimbingan kelompok dengan menggunakan media audio visual dapat dilihat pada gambar dibawah ini.

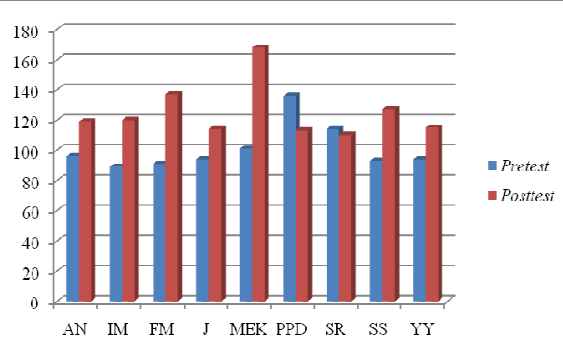

Gambar 1. Hasil Pretest dan Posttest Konsep Diri Masingmasing Siswa Kelompok Eksperimen

Berdasarkan gambar di atas, dapat dipahami bahwa terjadi peningkatan konsep diri pada tujuh orang siswa, dan terjadi penurunan pada dua orang siswa setelah mendapatkan layanan bimbingan kelompok dengan menggunakan media audio visual. Meskipun demikian, ratarata konsep diri siswa secara umum meningkat. Rata-rata pada pretest sebesar 100,89 dan pada posttest meningkat menjadi 124,78. Berdasarkan data hasil pretest dan posttest dengan menggunakan uji Wilcoxon Signed Ranks Test diperoleh hasil probabilitas Asymp. Sig. (2-tailed) konsep diri pada kelompok eksperimen sebesar 0,044 atau probabilitas di bawah Alpha $(0,044<0,05)$. Hal ini dapat dimaknaik bahwa hipotesis diterima, yaitu "Terdapat perbedaan yang signifikan terhadap konsep diri siswa kelompok eksperimen sebelum dan sesudah diberikan perlakuan bimbingan kelompok dengan menggunakan media audio visual".

\section{Konsep Diri Siswa Kelompok Kontrol}

Kondisi konsep diri siswa pada kelompok eksperimen sebelum dan sesudah diberikan perlakuan layanan bimbingan kelompok dengan menggunakan media audio visual dapat dilihat pada gambar berikut ini.

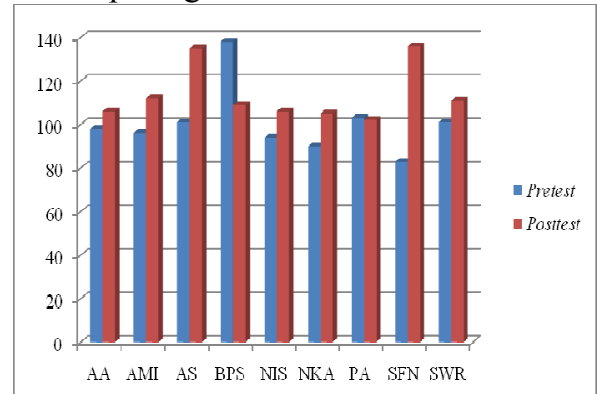

Gambar 2. Hasil Pretest dan Posttest Konsep Diri Masingmasing Siswa Kelompok Kontrol

Berdasarkan gambar di atas, dapat dipahami bahwa terjadi peningkatan konsep diri pada tujuh orang siswa, dan terjadi penurunan pada dua orang siswa setelah mendapatkan layanan bimbingan kelompok tanpa menggunakan media audio visual. Rata-rata pada pretest sebesar 100,44 dan pada posttest meningkat menjadi 113,56. Meskipun terdapat peningkatan pada posttest tapi tidak signifikan. Hal ini Berdasarkan uji Wilcoxon Signed Ranks Test diperoleh hasil probabilitas Asymp. Sig. (2-tailed) konsep diri pada kelompok kontrol sebesar 0,086 atau probabilitas di atas Alpha $(0,086>0,05)$. Berdasarkan hal tersebut maka hipotesis dapat diterima, yaitu "Tidak terdapat perbedaan yang signifikan terhadap konsep diri siswa kelompok kontrol sebelum dan sesudah diberikan perlakuan bimbingan kelompok tanpa menggunakan media audio visual".

\section{Perbedaan Konsep Diri Siswa Kelompok Eksperimen dan Kelompok Kontrol}

Kondisi konsep diri siswa pada posttest kelompok eksperimen dan kelompok kontrol dapat dilihat pada gambar berikut ini. 


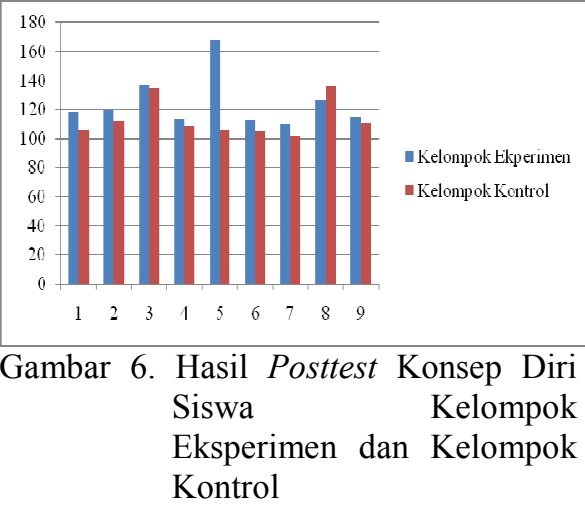

Berdasarkan gambar tersebut, dapat dipahami bahwa peningkatan konsep diri siswa kelompok eksperimen lebih baik jika dibandingkan dengan konsep diri siswa kelompok kontrol. Hasil posttest kelompok eksperimen sebesar 124,78 dan hasil posttest kelompok kontrol sebesar 113,56. Diketahui terdapat selisih skor posttest sebesar 11,22 antar kelompok eksperimen dan kelompok kontrol. Berdasarkan uji Kolmogorof Smirnof 2 Independent Samples diperoleh hasil Asymp. Sig. (2-tailed) untuk uji dua sisi dengan skor 0,037 atau probabilitas di bawah Alpha $(0,037<0,05)$. Berdasarkan perhitungan tersebut maka dapat dimaknai bahwa hipotesis diterima, yaitu "Terdapat perbedaan yang signifikan konsep diri siswa kelompok eksperimen yang diberikan layanan bimbingan kelompok dengan menggunakan media audio visual, dengan kelompok kontrol.yang diberikan layanan bimbingan kelompok tanpa menggunakan media audio visual".

\section{B. Pembahasan}

Temuan pada penelitian ini yaitu terdapat perbedaan yang signifikan pada konsep diri kelompok eksperimen dengan kelompok kontrol. Hasil penelitian tersebut selanjutnya akan dibahas secara konseptual agar lebih mudah dipahami.

\section{Perbedaan Konsep Diri Siswa pada Kelompok Eksperimen}

Hasil penelitian mengungkapkan bahwa konsep diri yang dimiliki oleh siswa sesudah mendapatkan layanan bimbingan kelompok dengan menggunakan media audio visual cenderung lebih baik dibandingkan sebelum mendapatkan perlakuan. Hal ini sesuai dengan pendapat peneliti bahwa konsep diri siswa dapat ditingkatkan melalui pemberian layanan bimbingan kelompok dengan menggunakan media audio visual. Pemberian layanan ini dapat meningkatkan skor konsep diri siswa yang signifikan. Hal ini berdasarkan hasil rata-rata skor kelompok eksperimen dari 100,89 menjadi 124,78. Berdasarkan peningkatan hasil tersebut, peneliti berpendapat bahwa keaktifan dan antusias siswa dalam mengikuti proses layanan, serta penggunaan media audio visual dalam layanan bimbingan kelompok berpengaruh terhadap hasil penelitian.

Pelaksanaan layanan bimbingan kelompok dengan menggunakan media audio visual bertujuan untuk meningkatkan konsep diri siswa. Pada pelaksanaannya, siswa diberikan layanan bimbingan kelompok dimana dalam tahap kegiatan siswa menyimak video berkaitan dengan materi yang sudah disiapkan oleh peneliti. Melalui layanan ini, siswa diajak ber-BMB3 mengenai materi yang telah dibahas bersama-sama, sehingga siswa dapat memperoleh pengetahuan dan pemahaman baru terkait dengan konsep diri yang dapat diterapkan dalam kehidupan sehari-hari.

Layanan bimbingan kelompok diberikan untuk memberikan kesempatan bagi siswa agar dapat terbuka, mampu memberikan ide atau gagasan, mampu menyampaikan perasaan, dukungan, memberikan alternatif pemecahan masalah, mengambil keputusan dan bertanggungjawab pada pilihan yang ditentukan. Kondisi tersebut didukung pendapat yang dikemukakan oleh Prayitno (2012:186) bahwa, layanan bimbingan kelompok tidak sekedar memberikan informasi kepada anggota kelompok dan para peserta juga tidak sekedar menerima informasi baru, namun lebih dari itu, para peserta tidak sekedar menunggu pemberian informasi melainkan sangat aktif saling memberi dan menerima informasi baru dari para anggota kelompok.

Layanan bimbingan kelompok dengan menggunakan media audio visual khususnya untuk meningkatkan konsep diri siswa efektif dalam mengembangkan konsep diri siswa. Hal ini karena layanan bimbingan kelompok dengan menggunakan media audio visual merupakan proses pemberian bantuan pada sekelompok orang dengan memanfaatkan dinamika kelompok guna 
mencapai suatu tujuan tertentu, dengan menggunakan media audio visual sebagai alat bantu untuk menyampaikan informasi secara lebih jelas dan menarik. Uraian tersebut didukung oleh pendapat Gavine dan Forsyth (dalam Kennedy, Landor, dan Todd, 2011:135) bahwa penggunaan media dalam layanan bimbingan konseling dapat memberikan perubahan informasi bagi siswa dan membantu komunikasi antara guru dan siswa, serta membantu mencapai hasil dan tujuan yang diinginkan dari pemberian layanan.

Media audio visual menurut Haryoko (2009:3) yaitu suatu alat yang digunakan untuk menyalurkan informasi atau pesan yang memiliki karakteristik audio (suara) dan visual (gambar). Media audio visual dalam penelitian ini digunakan untuk membantu memberikan pemahaman yang lebih jelas terhadap siswa mengenai konsep diri. Penggunaan media audio visual dalam penelitian ini bertujuan agar siswa lebih mudah memahami dengan menggunakan indera yang dimiliki untuk mendapatkan gambaran dan pemahaman konsep diri secara jelas ketika melihat contoh yang terkandung dalam media audio visual berupa video yang ditampilkan ketika kegiatan bimbingan kelompok berlangsung.

Berikut ini merupakan pendapat Nursalim dan Mustaji (2010:8) yang mendukung penggunaan media audio visual dalam layanan bimbingan kelompok pada penelitian ini, antara lain yaitu: "(a) Media bimbingan dan konseling merupakan wadah dari pesan, (b) materi yang ingin disampaikan adalah pesan bimbingan dan konseling, (c) tujuan yang ingin dicapai adalah perkembangan siswa secara optimal".

Adapun tujuan dalam penelitian ini adalah untuk meningkatkan konsep diri siswa secara optimal. Konsep diri merupakan gambaran diri yang dimiliki oleh seseorang mengenai seperti apa, mengapa, siapa, dan bagaimana seseorang memandang dirinya sendiri. Adanya konsep tersebut, maka peneliti memanfaatkan layanan bimbingan kelompok dengan menggunakan media audio visual untuk membantu siswa dalam meningkatkan konsep diri yang dimiliki.
Konsep diri yang terbentuk pada diri seseorang dipengaruhi oleh banyak faktor, baik faktor dari dalam maupun faktor dari luar diri individu. Begitu juga konsep diri yang terbentuk pada subjek penelitian melalui layanan bimbingan kelompok ini juga dipengaruhi oleh banyak faktor seperti ketertarikan siswa dalam mengikuti layanan, rasa percaya, dan keterikatan individu pada kelompok. Kondisi tersebut didukung oleh pendapat Burns (1993:281) bahwa, konsep diri terbentuk dikarenakan faktor pengalaman, keterbukaan dan kepekaan terhadap perasaan diri, terbuka dengan perasaan orang lain, dan realitas yang ada di lingkungan.

Berdasarkan hasil temuan penelitian pada uraian sebelumnya dan pendapat dari para ahli yang saling mendukung satu sama lain, maka layanan bimbingan kelompok dengan menggunakan media audio visual dapat bermanfaat untuk meningkatkan konsep diri siswa.

\section{Perbedaan Konsep Diri Siswa pada Kelompok Kontrol \\ Hasil penelitian menunjukkan} bahwa konsep diri yang dimiliki oleh siswa kelompok kontrol sesudah mendapatkan layanan bimbingan kelompok tanpa menggunakan media audio visual terdapat peningkatan dibandingkan sebelum mendapatkan layanan bimbingan kelompok. Namun, peningkatan ini tidak signifikan jika dibandingkan dengan kelompok eksperimen. Hasil penelitian menggambarkan bahwa variabel konsep diri memperoleh $\mathrm{Z}$ skor sebesar -1,718 dan angka probabilitas di atas Alpha $(0,086>0,05)$. Hasil perhitungan tersebut dapat dimaknai bahwa tidak terdapat perbedaan yang signifikan terhadap konsep diri sebelum dan sesudah diberikan perlakuan berupa layanan bimbingan kelompok tanpa menggunakan media audio visual.

Pada kelompok kontrol, upaya yang dilakukan untuk meningkatkan konsep diri siswa menggunakan layanan bimbingan kelompok tanpa menggunakan media audio visual. Layanan bimbingan kelompok diberikan pada kelompok kontrol, dengan cara siswa diberikan topik tugas yang berkenaan dengan variabel penelitian yaitu konsep diri, untuk dibahas dalam 
kelompok. Pembahasan yang dilakukan pada kelompok kontrol dilakukan oleh anggota kelompok yang dipimpin oleh pemimpin kelompok. Pada pembahasan, pemimpin kelompok mengemukakan contoh dalam kehidupan sehari dengan cara menceritakan kepada anggota kelompok. Sedangkan anggota kelompok menyimak dan memahami contoh-contoh yang disampaikan oleh pemimpin kelompok.

Sesuai dengan tujuan pemberian layanan, yaitu untuk meningkatkan konsep diri siswa. Pada kelompok kontrol setelah diberikan layanan dan dilakukan posttest, diperoleh hasil bahwa konsep diri siswa meningkat. Meskipun demikian, perubahan konsep diri pada kelompok kontrol tidak meningkat secara signifikan. Kondisi tersebut diduga karena kondisi ruang, konsentrasi, suasana yang tidak nyaman, keseriusan, dan minat siswa dalam mengisi pretest dan posttest. Pengadministrasian posttest dilakukan di ruang bimbingan kelompok yang sangat luas, namun tidak memiliki fasilitas meja dan kursi sehingga siswa harus duduk di lantai yang diberi alas karpet. Faktor lain yang mempengaruhi yaitu suasana di luar ruang bimbingan kelompok yang sangat ribut dan ramai karena berdekatan dengan kantin sehingga menyebabkan konsentrasi siswa berkurang. Kondisi ini sejalan dengan pendapat Suryabrata (2010:233) tentang faktor yang mempengaruhi proses belajar yaitu faktor internal dan faktor eksternal, faktor internal berupa kondisi fisiologis dan psikologis, sedangkan faktor eksternal berupa kondisi lingkungan.

Berdasarkan uraian di atas, maka diperoleh kesimpulan bahwa konsep diri siswa kelompok kontrol tidak mengalami peningkatan yang signifikan karena banyak faktor yang mempengaruhi di antaranya, kondisi lingkungan, kenyamanan, keseriusan, dan minat dalam mengikuti posttest.

\section{Perbedaan Konsep Diri Siswa pada Kelompok Eksperimen dan Kelompok Kontrol}

Hasil penelitian menunjukkan bahwa terdapat perbedaan konsep diri siswa kelompok eksperimen dan kelompok kontrol. Hal ini berdasarkan gambaran hasil penelitian bahwa variabel konsep diri memperoleh $\mathrm{Z}$ skor sebesar
1,414 dan angka probabilitas di bawah Alpha $(0,037<0,05)$. Hasil perhitungan tersebut menunjukkan bahwa terdapat perbedaan yang signifikan pada konsep diri siswa kelompok eksperimen yang diberikan perlakuan layanan bimbingan kelompok dengan menggunakan media audio visual, dengan siswa kelompok kontrol yang diberikan perlakuan layanan bimbingan kelompok tanpa menggunakan media audio visual.

Perbedaan hasil konsep diri pada kelompok eksperimen dan kelompok kontrol diduga karena adanya perbedaan perlakuan yang diberikan pada dua kelompok tersebut. Pada kelompok eksperimen, bimbingan kelompok diberikan dengan menggunakan tambahan media audio visual, sedangkan untuk kelompok kontrol tidak diberikan tambahan media audio visual. Hasil temuan tersebut didukung oleh pendapat Mishra dan Sharma (2005:2) yang mengemukakan bahwa, multimedia efektif digunakan dalam pembelajaran yang terbuka dan jarak jauh, tergantung pada berbagai faktor media itu sendiri dan hal-hal yang berkaitan dengan perbedaan tujuan pedagogik dan lingkungan organisasi dimana media digunakan. Penggunaan media bermanfaat pada praktik pengajaran dan pembelajaran, karena hal ini akan cenderung berbeda dari pembelajaran biasa.

Media audio visual yang digunakan dalam penelitian ini berupa video. Penggunaan media audio visual yang berupa video pada kelompok eksperimen berfungsi agar siswa memperoleh contoh gambaran secara jelas, yang dalam penelitian ini mengenai variabel konsep diri. Hasil temuan tersebut sesuai dengan pendapat yang dikemukakan oleh Mishra dan Sharma (2005:5) bahwa video dapat digunakan untuk menunjukkan tindakan dan proses yang menggambarkan peristiwa yang tidak dapat dilihat secara langsung.

Perbedaan hasil konsep diri pada kelompok eksperimen dan kelompok kontrol diduga selain karena faktor media perlakuan yang berbeda juga disebabkan karena hubungan atau interaksi seseorang dengan lingkungan sekitar, pengamatan terhadap diri sendiri, dan pengalaman dalam kehidupan sehari-hari. Kondisi tersebut sesuai dengan pendapat yang 
dikemukakan oleh Thalib (2010:122) bahwa, "Konsep diri merupakan gambaran diri, penilaian diri, dan penerimaan diri yang bersifat dinamis, terbentuk melalui persepsi dan interpretasi terhadap diri sendiri dan lingkungan". Adanya interaksi dengan lingkungan, terutama teman sebaya dapat mempengaruhi hasil konsep diri siswa, seperti pendapat berikut yang dikemukakan oleh Blyth dan Traeger (2014:92) bahwa melepaskan diri dari orangtua dan mendapat pengaruh dari teman dapat memberikan perubahan besar dalam berinteraksi dan bagaimana orang lain melihat dirinya. Seiring dengan frekuensi dan intensitas perubahan tersebut, kemungkinan juga terdapat perubahan harapan orang lain. Perubahan tersebut kemungkinan berpengaruh pada konsep diri individu dan juga mempengaruhi kepuasan seseorang terhadap diri sendiri.

Berdasarkan data yang diperoleh selama penelitian berlangsung, yaitu pemberian perlakuan pada kelompok eksperimen dan kelompok kontrol, diperoleh keterangan dari Konselor yang bertindak sebagai pimpinan kelompok dalam pemberian layanan bimbingan kelompok. Adapun penjelasan yang diberikan oleh Konselor bahwa layanan bimbingan kelompok diberikan kepada kedua kelompok, yaitu kelompok eksperimen dan kelompok kontrol dengan kondisi dan situasi lingkungan yang sama. Kelompok eksperimen dan kelompok kontrol sama-sama diberikan layanan dalam ruang bimbingan kelompok yang beralas karpet. Adapun proses pemberian layanan pada kelompok eksperimen dan kelompok kontrol cenderung sama baik dari segi materi, permainan, dan juga cara penyampaian dan pembahasan topik oleh pemimpin kelompok. Hal yang membedakan antara kelompok eksperimen dan kelompok kontrol yaitu dalam hal durasi waktu layanan. Pada kelompok eksperimen, waktu yang digunakan cenderung lebih lama jika dibandingkan dengan kelompok kontrol. Hal ini karena, pada kelompok eksperimen diberikan tambahan media audio visual pada tahap kegiatan, sedangkan untuk kelompok kontrol tidak diberikan media tambahan.

Selama proses pemberian layanan berlangsung, anggota pada kelompok eksperimen cenderung lebih antusias dan lebih mudah memahami materi yang dibahas bersama-sama jika dibandingkan dengan kelompok kontrol. Hal ini diduga karena pada kelompok eksperimen pemberian materi didukung oleh pemberian tambahan media yang dapat membantu anggota kelompok untuk mengetahui dan memahami materi. Melalui video yang ditayangkan, anggota kelompok eksperimen dapat lebih mudah mengetahui contoh materi dalam kehidupan sehari-hari secara konkrit. Sedangkan pada kelompok kontrol, pemimpin kelompok harus menceritakan contoh-contoh materi dalam kehidupan sehari-hari dan anggota kelompok hanya dapat membayangkan dan memahami contoh yang diceritakan oleh pemimpin kelompok tanpa melihat jelas gambaran dalam kehidupan sehari-hari. Hal ini memungkinkan anggota kelompok salah dalam mempersepsikan apa yang dimaksud oleh pemimpin kelompok. Adanya perbedaan tersebut diduga menajadi faktor yang menyebabkan perbedaan hasil posttest pada kelompok eksperimen dan kelompok kontrol.

\section{KESIMPULAN DAN SARAN \\ A. Kesimpulan}

Berdasarkan hasil penelitian yang diperoleh melalui analisis statistik dan uji hipotesis yang telah dilakukan, maka dapat disimpulkan secara umum bahwa layanan bimbingan kelompok dengan menggunakan media audio visual efektif dapat meningkatkan konsep diri siswa. Berikut ini dijelaskan kesimpulan secara khusus.

1. Terdapat perbedaan yang signifikan konsep diri siswa kelompok eksperimen sebelum dan sesudah diberikan perlakuan bimbingan kelompok dengan menggunakan media audio visual. Perbedaan tersebut berupa peningkatan konsep diri, yaitu pada pretest memiliki rata-rata 100,89 dengan kategori kurang baik, sedangkan pada posttest meningkat menjadi 124,78 dengan kategori cukup baik.

2. Tidak terdapat perbedaan yang signifikan konsep diri siswa kelompok kontrol sebelum dan sesudah diberikan perlakuan bimbingan kelompok tanpa menggunakan media audio visual. Hasil pada pretest memiliki rata-rata 100,44 dengan kategori kurang baik, sedangkan 
pada posttest memiliki rata-rata 113,56 dengan kategori cukup baik.

3. Terdapat perbedaan yang signifikan antara konsep diri siswa kelompok eksperimen yang diberikan perlakuan layanan bimbingan kelompok dengan menggunakan media audio visual, dengan siswa kelompok kontrol yang diberikan perlakuan layanan bimbingan kelompok tanpa menggunakan media audio visual. Perbedaan tersebut berupa peningkatan konsep diri yang lebih tinggi pada kelompok eksperimen dengan ratarata pada posttest 124,78 dan berada pada kategori cukup baik. Pada kelompok kontrol rata-rata pada posttest 113,56 dan berada pada kategori cukup baik.

\section{B. Implikasi}

Hasil yang diperoleh melalui penelitian eksperimen ini dapat dijadikan sebagai bahan masukan bagi Guru BK atau Konselor di sekolah dan personil sekolah lainnya dalam menyikapi rendahnya konsep diri siswa, sehingga dapat memberikan pelayanan yang tepat untuk diberikan kepada siswa. Melalui kegiatan layanan bimbingan kelompok dengan menggunakan media audio visual, Guru BK atau Konselor dapat memberikan contoh gambaran konsep diri secara jelas dalam kehidupan sehari-hari. Hendaknya pelaksanaan layanan bimbingan kelompok dengan menggunakan media audio visual dapat menjadi alternatif layanan BK yang pelaksanaanya dapat lebih diintensifkan. Oleh karena itu perlulah peran serta yang aktif dari kepala sekolah untuk dapat menyediakan fasilitas yang dapat mendukung terlaksananya layanan bimbingan kelompok dengan menggunakan media audio visual; Guru BK atau Konselor sekolah sebagai pelaksana layanan bimbingan kelompok dengan menggunakan media audio visual; dan peran aktif siswa dalam mengikuti layanan yang diberikan oleh Guru BK di sekolah. Temuan ini dapat menjadi masukan bagi semua pihak yang terlibat dengan proses pendidikan baik di sekolah maupun di luar sekolah, karena dengan adanya perhatian semua pihak akan menjadikan siswa sebagai individu yang memiliki kepribadian positif yang lebih optimal.

\section{Saran}

Berdasarkan hasil penelitian maka dapat diajukan beberapa saran sebagai tindak lanjut penelitian ini yaitu:
1.Bagi Guru BK atau Konselor Sekolah disarankan untuk dapat menggunakan layanan bimbingan kelompok dengan menggunakan media audio visual untuk meningkatkan konsep diri siswa dan variabel-variabel lain yang disesuaikan dengan situasi, kondisi, dan kebutuhan siswa di sekolah.

2.Bagi Kepala Sekolah

a. Dapat memberikan fasilitas berupa peralatan yang dapat digunakan untuk menunjang terlaksananya layanan bimbingan kelompok dengan menggunakan media audio visual.

b. Diharapkan untuk dapat bekerjasama dalam membantu siswa dalam meningkatkan konsep diri, sehingga siswa dapat memiliki kepribadian positif yang dapat bermanfaat dalam kehidupan sehari-hari.

3.Bagi Peneliti Lain

a. Dapat mengembangkan penelitian terkait dengan penggunaan media audio visual untuk meningkatkan variabelvariabel lain.

b. Hasil penelitian ini dapat dijadikan dasar penelitian lanjutan mengenai layanan bimbingan kelompok dengan menggunakan media audio visual untuk meningkatkan konsep diri siswa.

4.Bagi Musyawarah Guru BK (MGBK), sebagai bahan kajian dalam pertemuanpertemuan yang membahas tentang konsep diri dan layanan bimbingan kelompok serta penggunaan media dalam memberikan layanan, terutama media audio visual.

5.Bagi dinas pendidikan, sebagai bahan masukan untuk merumuskan dan mengambil kebijakan dalam mengatasi permasalahan siswa terutama yang berkenaan dengan konsep diri.

6.Bagi Lembaga Pendidikan Tenaga Kependidikan (LPTK), sebagai bahan masukan untuk revitalisasi kurikulum dengan memanfaatkan media sebagai alat bantu pendidikan, terutama dalam layanan BK yang berkenaan dengan media audio visual.

\section{DAFTAR RUJUKAN}

Blyth, D.A., dan Traeger, C.M. 2014. The Self Concept and Self Esteem of Early Adolescents. Theory into Practice, (Online), Vol. 22, No. 2, (http://www.jstor.org/stable/1477149, diakses 22 Oktober 2015). 
Burns, R.B. 1993. Konsep Diri (Teori, Pengukuran, Perkembangan, dan Perilaku). Terjemahan oleh Eddy. 2004. Jakarta: Arcan.

Feldman, P.O. 2008. Human Development (Perkembangan Manusia) Edisi 10 Buku 1. Terjemahan oleh Brian Marswendy. 2009. Jakarta: Salemba Humanika.

Haryoko, S. 2009. "Efektivitas Pemanfaatan Media Audio Visual sebagai Alternatif Optimalisasi Model Pembelajaran". Jurnal Edukasi Elektro, (Online), Vol. 5, No. 1, hlm. 1-10, (journal.uny.ac.id/index.php/jee/article/ download/972/781, diakses 5 Februari 2015).

Hurlock, E.B. 1980. Psikologi Perkembangan (Suatu Pendekatan Sepanjang Rentang Kehidupan) Edisi Kelima. Terjemahan Istiwidayanti dan Soedjarwo. Tanpa Tahun. Jakarta: Erlangga.

Kennedy, H., Landor, M., dan Todd, L. 2011. Video Interaction Guidance. London: Jessica Kingsley.

Mishra, S., dan Sharma, R.C. 2005. Interactive Multimedia in Education and Training. USA: Idea Group Publishing.

Nursalim, M., dan Mustaji. 2010. Media Bimbingan dan Konseling. Surabaya: Unesa University Press.

Prayitno, E. 2006. Psikologi Perkembangan Remaja. Padang: Angkasa Raya.

Prayitno. 2012. Jenis Layanan dan Kegiatan Pendukung Konseling. Padang: Program PPK Jurusan BK UNP.

Suryabrata, S. 2010. Psikologi Pendidikan. Jakarta: Rajawali Press.

Thalib, S.B. 2010. Psikologi Pendidikan Berbasis Analisis Empiris Aplikatif. Jakarta: Kencana. 